\title{
Communalization of Minorities' Demands in Sri Lanka: The Case of Kalmunai Administrative District Demand
}

\author{
Mohammad Agus Yusoff \\ School of History, Politics and Strategic Studies, Faculty of Social Sciences and Humanities, \\ Universiti Kebangsaan Malaysia, UKM Bangi 43600, Selangor, Malaysia \\ E-Mail: agus_ukm@yahoo.com \\ Athambawa Sarjoon \\ School of History, Politics and Strategic Studies, Faculty of Social Sciences and Humanities, \\ Universiti Kebangsaan Malaysia, UKM Bangi 43600, Selangor, Malaysia \\ Department of Political Science, University of Peradeniya, Sri Lanka \\ E-mail: sarjoona@gmail.com
}

Doi:10.5901/jesr.2016.v6n3p99

\section{Abstract}

In Sri Lanka, minorities have been facing a number of issues and challenges relating to public administration. When they put forward their reasonable demands, those demands are over-communalized by the ethnic majorities, resulting in them to be continuously sidetracked. The Kalmunai administrative district demand is an example of such a demand which has been highly communalized by recent politics, even though it merely advocates the establishment of an administrative district-an intermediate decentralized administrative institution-in order to improve delivery of public service, enhance regional and economic development, and facilitate linguistic functions in district administration for those living on the coastal belt of the Amparai district. This study examines the extent of the ethnicization and communalization of the Kalmunai administrative district demand, by examining in detail the viewpoints taken by the major ethnic groups and their political parties on the subject. The findings of this study reveal that although the demand advocated a mere form of decentralization initiative-also known as de-concentration-the demand was over-communalized and opposed by other ethnic groups and the political forces representing them. They misunderstood the demand to be one calling for political autonomy and separation. This study finds that rationalist views of the demand taken by ethnic majorities and major political parties would help to resolve the administrative grievances of minorities and achieve the accommodation of the Kalmunai administrative district demand within the larger political system in Sri Lanka.

Keywords: Sri Lanka, Ethnic Politics, Minorities, Kalmunai District Demand, Communalization

\section{Introduction}

The occurrence of ethnic conflicts and the development of ethnic politics in Sri Lanka have led to the emergence of ethnocentric demands within the minority groups. The continued sidetracking of the Tamils' interests (for example, in terms of recognizing their linguistic rights and sharing power within the larger political system) had induced them to demand equal rights and political autonomy, subsequently followed by a demand for a separate state for their predominant area. Similarly, the domination of political and administrative affairs by the ethnic majorities and the continued sidetracking of the interests of the Muslims, particularly in the north-eastern region, induced the Muslims to call for more political and administrative autonomy in their predominant areas. The Kalmunai administrative demand is one such demand which has been advocated mostly by the Muslim community living on the coastal belt of the Amparai district, as a response to the domination by the ethnic majority, the violation of their linguistic rights, and the marginalization of their interests in the district administration of Amparai (See: Ibrahim, 2002; Mohideen, 2013 \& Sarjoon et al., 2015).

The Kalmunai administrative district demand is a proposal for the government authorities to establish a separate administrative district for the coastal area of the present Amparai district as a mechanism to improve public service delivery, induce institutional capacity for socio-economic development of the region, and overcome the linguistic issues which exist in the district administration. Although the demand emerged on rational grounds and was initially advocated 
by both the Tamils and the Muslims under the slogan of "Tamil-speakers," the intense civil war which took place since the middle of 1980s led the demand being mostly advocated by the Muslims alone as a solution to resolve a number of administrative issues. The other ethnic groups, such as the Tamils and the Sinhalese living within and outside the proposed district, continued to view the demand as ethnocentric, criticizing and opposing it on this basis. For the last three decades, the demand has received significant ethnic and communal criticisms and oppositions in its process of political advocacy. This study seeks to examine why the demand has continuously been opposed on communal lines, despite the fact that the establishment of a new administrative district and an administrative machinery - known as the District Secretariat-would result in a mere form of decentralized power (i.e., de-concentration) and will not offer political autonomy for the Muslims of the region in the Sri Lankan context.

The main objective of this study is to analyze the extent of the communalization of the demand in its political advocacy process. The following section summarizes the materials and methods adopted in this study. Next, a brief look at the contents of the Kalmunai administrative district demand and an examination of the communalization of the Kalmunai administrative district demand will be made by analyzing the stance taken by the major ethnic groups and the major political parties towards the same. The final part of this study examines the truth of the communalization of the Kalmunai administrative district demand, and its impact on the advocacy process and the fulfillment of the demand.

\section{Research Materials and Methods}

This paper is one of the outcomes of a 3-year research project which extensively studied the Kalmunai administrative district demand by using the method of case study. Basically, a case study entails a detailed analysis of a single case. This study capitalized on two forms of data: primary data and secondary data collected from different sources. In gathering primary data related to the case study, several types of sources have been relied upon. These include interviews conducted with high level political and administrative officials, in-depth interviews with a number of key informants, and focus group discussions. Accordingly, semi-structured interviews with cabinet ministers, parliamentarians, former parliamentarians, provincial councilors, and representatives of local government bodies were conducted. Further, a series of in-depth interviews and focus group discussions were also conducted with key high level administrative officials, academicians, educationists, journalists, civil activists, and members of the general public (selected from three different ethnic communities living in different parts of the research area) who have shown their interest and clear understanding of the core issues surrounding the study, in order to understand the views of each of the ethnic groups and major political parties on the subject of the Kalmunai administrative district demand.

Meanwhile, secondary data were collected from several relevant sources through the method of desk analysis of existing literature which were available in the form of academic journal articles and periodicals, thesis and dissertations, literary publications (including books from selected public and university libraries and research-based centers), newspaper cuttings, government reports, and laws passed by the Sri Lankan parliament. Based on these primary and secondary data, the various perspectives of major ethnic groups and political parties towards the Kalmunai administrative district demand were analyzed and presented in the form of direct quotations, summaries of interviews and reports, as well as interpretive arguments.

\section{The Kalmunai Administrative District Demand: A Brief Background}

For the last five decades, the people living on the coastal belt of the present Amparai district have been urging the government authorities to form a separate administrative district covering the three coastal electorates, namely, Kalmunai, Sammanthurai and Pottuvil. The coastal belt of the Amparai district has been considered as a separate region in the administration of a number of matters, such as education, healthcare, transportation, irrigation, and telecommunication, and has been referred to as "Kalmunai" or the "South-Eastern Region." The people living in this region have been demanding a separate administrative district (referred to as "Kalmunai") as a mechanism to facilitate the functions of public administration, based on the justification that the district administrative machinery-namely, the District Secretariat and other government departments-are dominated by the Sinhalese, communicate in Sinhala language and are located closer to the Sinhalese predominant settlements, despite the fact that the majority of the districts' population are Tamil-speakers (Muslims and Tamils) who are predominantly living on the coastal belt of the district. Tamil-speakers have continuously been discriminated against and marginalized in matters of district administration, resource allocation, and development initiatives (Ibrahim, 2002; Sarjoon at el., 2015 \& Yusoff et al., 2015a). This demand has been prevailing at societal and political levels for the last 50 years and has in recent years 
been a contested topic of discussion and debate in the Muslim as well as in national politics in Sri Lanka.

The parties and organizations advocating the formation of a Kalmunai administrative district have requested for the area covering three coastal electorates of the present Amparai district, namely Sammanthurai, Kalmunai and Puttuvil, to be declared as a separate administrative district. Accordingly, the proposed new district would cover an area of 1867.7 square kilometers, which amounts to about 40 percent of the total land area of the existing Amparai district (See: Ibrahim, 2002; Jabbar, 2013:83; Mohideen, 2013:51 \& Sarjoon et al., 2015). According to Sri Lanka's 2012 census, the proposed district would have a population of 409,260 , which is equivalent to 63 percent of the total population of the present Amparai district. Out of this, the Muslims constitute 68.60 percent, the Tamils 27.40 percent while the Sinhalese constitute only 3.5 percent (Department of Census and Statistics 2014). Although the proposed Kalmunai district comprises a predominantly Tamil-speaking population, the district is still an ethnically plural one. Sri Lanka's major ethnic groups-the Sinhalese, the Tamils, and the Muslims-all live in this proposed district. The concentration of Muslims in this area has a long history and they also have a long tradition of relations with the other ethnic groups in the region. Since the Muslim, Tamil, and Sinhalese settlements are located next to one another, this geographical factor has forced them to co-exist and has also strengthened the social and ethnic relations among them (Habullah et al., 2005 \& Rameez Abdullah, 2005).

\section{Kalmunai Administrative District Demand Under Majoritarian Communal Threats: Major Findings}

As briefly mentioned at the start of this paper, the demand for an administrative district in the coastal belt of the Amparai district was initially welcomed and supported by Tamils and their political and community leaders living within and outside the proposed district. However, in due time, they changed their stance and began to criticize and oppose the demand, along with the Sinhalese who have always opposed it. Oppositions posed by the other ethnic groups became severe when the Muslims started to seriously advocate the demand, especially from 2000 onwards. This study identifies the nature and the changing dynamics of the criticisms posed by the other ethnic groups and the political parties representing them as being among the major challenges faced in the process of advocating the Kalmunai administrative district demand by the Muslim community. The following sub-topics provide an extensive analysis on this subject.

\subsection{Opposition and Criticism from Major Ethnic Groups}

\subsubsection{Opposition and Criticisms from the Sinhalese}

Since the Sinhalese have been living a distance away from the settlement of the Tamil-speakers, their interactions with the people of the coastal area were limited in the Amparai district. Initially, there was no opposition to the Kalmunai district demand from the Sinhalese living in the Amparai area. However, in due time, especially with the intense of ethnic conflict and violent civil war, the Sinhalese viewed the demand as being ethnocentric and therefore opposed it. Later, they labeled it as a demand threatening the territorial integrity of the country. It is noted that whenever the demand was placed on the political negotiation tables by the Muslim political parties and social forces, the Sinhalese political parties and nationalist forces mobilized the local masses in the Amparai area to oppose the demand. In this regard, the antidemand opposition and the people march staged by the Janata Vimukthi Peramuna (JVP) in May 2001, with the help of many other local political and social forces, serve as among the best examples of this (See: Ibrahim, 2002; Thinakkural, 2001:1 \& Veerakesari, 2001:1).

The Sinhalese's opposition to the proposed Kalmunai administrative district emerged mainly from the lack of understanding by the Sinhalese political parties, nationalist forces, and their leaders, who misinterpreted the proposal for a Muslim-majority administrative district as an attempt to achieve a Muslim-majority political autonomous unit in which administration and politics will be highly dominated by the Muslims. In Sri Lankan context, an administrative district functions as an intermediate institution in the decentralized administrative machinery and it exercises a mere form of decentralized administrative power-de-concentration. There is no room for power politics or representative politics at district secretariat. Therefore, this justifies the political motives behind the oppositions expressed by the Sinhalese politicians of Amparai to the Kalmunai administrative district demand. Until 1994, Sinhalese politicians have headed the District Political Authority (DPA), the District Development Council (DDC), and the District Coordinating Committee (DCC) in Amparai district. In this way, they were able to control the District Secretariat. They planned and implemented a number of ethnic-oriented development programs which were immensely helpful in uplifting the socio-economic status of their (Sinhalese) community. This in turn led to the deprivation and marginalization of the Tamil-speakers in the coastal 
area (Mohideen 2008; Mohidden 2013 \& Sarjoon et al., 2015). The Sinhalese had also benefited in electoral politics from the loss of due representation of Tamil-speakers in the district (See: Sarjoon et al., 2015). Therefore, the Sinhalese politicians and community began to express their opposition towards the formation of a new district within the district, as it would limit the utilization and allocation of resources needed to develop their own areas. Similarly, with the introduction of PR electoral system, the Sinhalese benefited politically and this automatically gave them political authority in respect of the affairs of district administration. As indicated by IN.01 (Personal communication, 14 July, 2014) and IN.02 (Personal communication, 22 August, 2014), the Sinhalese have been criticizing and opposing the demand primarily because they were not willing to lose their political privileges experiencing in the present Amparai district.

When the Muslims gained due political representation through the Muslim political party, especially from 1994 onwards, the Kalmunai administrative district demand correspondingly also gained political importance. It was discussed at cabinet meetings and negotiation tables. This further promulgated the idea among the Sinhalese political leaders and nationalist forces that if the demand is fulfilled, they would lose their political power and privileges in the district. Therefore, whenever negotiations were held on the subject, the Sinhalese politicians mobilized the local public to express their protest in various forms of agitation and violence, and by presenting petitions to the central political authority. It is noteworthy that most of the oppositions and criticisms put forward by the Sinhalese were mostly developed and articulated by the Sinhalese political parties and nationalist forces functioning at the central level, and not at district level.

In the course of time, at an extreme level, the Sinhalese labelled this demand as a demand to divide the country, equating it with the Tamil Tigers' (LTTE) demand for a separate state. Especially following the end of the civil war with the LTTE in May 2009, and with the re-emergence of the Sinhala hegemonic nationalist forces that are voicing to protect and promote the Sinhalese-Buddhist ethno-religious aspects while targeting the ethnic minorities, the Kalmunai administrative district demand was hugely criticized and was interpreted in various negative forms. As part of an antiMuslim discourse, the Sinhalese forces labelled the Kalmunai district demand as being an initial step towards the formation of a Muslim state and thereby claimed that the Muslim politicians are challenging the national and territorial integrity of the nation. Interestingly, it is noted that during the pre-presidential election in January 2015, the demand received strong opposition from the Sinhalese political parties and nationalist forces which had to a certain extent supported it in the past.

As part of this study, a field survey using personal interviews and target group discussions was conducted in Sinhalese areas (especially in two villages predominantly inhibited by Sinhalese) in the proposed district. The objective of the field survey was to identify the interviewees' level of understanding of the Kalmunai district demand and to gain some insights on their viewpoints on the subject. A majority of the interviewees who participated in the focus group discussions displayed negative sentiments regarding the establishment of the proposed district for various reasons. Many of the ordinary villagers were not really aware of the demand; hence they did not strongly oppose it. Although some educated members of the public and politicians understood the rationale for the formation of a new district, they were against the idea of their villages being part of the new district for fear of ethnic domination by the Muslims and ethnic marginalization of the Sinhalese under the administration of the new district. They feared that the new district will function in Tamil language, which would cause them difficulties and marginalize their interests in the district administration (IN.03-05, Personal communications, 17 August, 2014 \& 30 August, 2014). Many, especially the local politicians, also expressed their dislike for their villages to form part of the new district due to the the opportunistic politics of the Muslim leaders. The chairman of the Lahugala local government body (Pradesiya Sabah), the one and only Sinhalese-majority local government unit which would come under the proposed district, openly criticized the opportunistic politics practiced by the Muslim leaders. According to him, despite the assurances given by the Muslim leaders concerning the safety and equal treatment of the Sinhalese in the proposed district administration, the honesty of the Muslim politicians in respecting and implementing their assurances is always questionable (IN.06, Personal communication, 17 August, 2014). Therefore, fear is prevalent among the Sinhalese that if the new district is formed, their villages would be marginalized and they would experience discrimination by the district administration. On the other hand, even though a few Sinhalese had expressed their supports for the establishment of the new district, they still prefer for their villages to be merged and administered together with the neighboring Sinhalese-majority districts, for the sake of administrative ease and linguistic convenience.

From the interviews conducted, another negative viewpoint was discovered among the Sinhalese, especially among the government officers and hard-liner, regarding the establishment of the proposed Kalmunai administrative district. Many of them justified their oppositions or dislike for the demand on grounds that there is no strong rationale for the formation of an administrative district by dividing the existing Amparai district. According to them, Tamil-speakers do not face any linguistic problems in accessing the services provided by the District Secretariat. Similarly, they argued that 
a majority of the public in the district can fulfill their necessary administrative tasks at the local level since most of the functions of a District Secretariat have been transferred to Divisional Secretariat (DS) offices by virtue of the 1992 Act. Accordingly, a very low percentage of the administrative functions handle by the District Secretariat and therefore, it serves as merely as a coordinating and monitoring institution. Further, they argued that there are Tamil-speakers living in many Sinhalese-majority districts and Sinhalese-speakers in Tamils-majority districts in other parts of the country, but they never made demands for the establishment of a new district for the sake of their administrative ease. They contend that dividing the country on an ethnic basis is dangerous as it would challenge the country's territorial integrity, ethnic relations, and societal harmony at the local level (IN.07-09, Personal communications, 30 August, 2014).

A field visit was conducted at the Amparai District Secretariat building complex to observe the working environment of the premises. There were signboards put up in all three official languages. However, no Tamil-speaking officer was placed in any major sections at the front office and reception area to respond to any basic inquiries. Although there were a few Tamil-speaking officers in each section of the secretariat, the normal routine of the secretariat was carried out in the Sinhala language, with most of the Tamil-speaking officers having been placed out of public contact. It was also noted that most of the members of the public were normally spoken to in Sinhala language and this caused difficulties for most of them. Therefore, a majority of the Tamil-speakers come to the District Secretariat with an interpreter or an assistant. Further, many Tamil-speakers have expressed their concerns pertaining to linguistic issues and the treatment they received from the officers. A majority of the ordinary members of the public and interviewees involved in the field survey also indicated that the linguistic problems which they face at the District Secretariat is one of the root factors motivating them to demand for a separate administrative district, in order to facilitate the needs of Tamilspeakers in district administration.

This study has also found that there are no strong reasons to support the Sinhalese's belief that the demand for a new Muslim-majority administrative district equals the formation of an autonomous political unit or a new state for Muslims. These criticisms have basically emerged due to the lack of understanding of the Kalmunai district demand and the system of district administration in general. In Sri Lanka's administrative context, a district is an administrative unit and the District Secretariat merely facilitates the administrative machinery of the central government through exercising the decentralized powers delegated by the central government authorities (See: Leitan, 1979 \& Yusoff et al., 2015b). The District Secretariat and all the officers working there are under the full control of the central government or the relevant line ministries. The nature and extent of decentralized administrative powers delegated to the District Secretariat is a very weak form - referred to as de-concentration - in decentralization literatures. Therefore, a district is not a politicallyempowered institution in Sri Lanka. There are also provinces and local government bodies which are empowered with decentralized political powers and authorities. To be clear, the demand advocated by the people of the coastal belt of the Amparai district is merely for an administrative unit (district) which enjoys decentralized administrative powers. The only similarity between the demand for the proposed administrative district and a Muslim-majority political autonomous unit is that the territory in question is probably the same. The demand for a Muslim autonomous unit has always been strongly opposed by many Sinhala nationalists forces whenever it was put forward at the political negotiation table (See: Sarjoon, 2011 \& Yusoff et al., 2014). With that background, the supporters of these nationalist forces view this proposed administrative district as the initial step to form a Muslim-majority autonomous unit or a state. Further, they find the formation of an administrative district based on ethnic or racial lines as divisive, being a sure recipe for disaster. However, it has to be said that for rationalists, the difference between a state and a district should be obvious.

The other reason given by the Sinhalese to justify their opposition to the Kalmunai district demand is their belief that the hidden objective of the Muslims in demanding for the new administrative district is to grab more governmental land including the protected jungles and archeological sites (most probably the Deegawaapi sacred area) and to issue more land permits to the Muslims (Pradeep, 2008). They question the Muslims' claims of allocating more land according to the percentage of their ethnic composition. Further, they claim that the present day Amparai belongs to the ancient Anuradhapura Kingdom and later to Kandyan Kingdom, where the Muslims were settled only on the coastal belt of the district. According to them, the Sinhalese who inhibited the Amparai and other parts of the eastern province after 1921 were settled in parts of land that had belonged to the Kandyan Kingdom, not along the coastal strip on which King Senarat settled the Muslims facing the wrath of the Portuguese. Therefore, there is no basis for the Muslims' claims that the Sinhalese government had seized their land for Sinhalese settlements and other economic purposes (Pradeep, 2008). In line with this, a majority of the Sinhalese opponents view this district demand as a way for the Muslims to grab more government land in the district, under the control of the new District Secretariat. However, it is obvious that the proposed new district will only cover the inhabitant areas of coastal stretch where the Tamil-speakers predominantly lived, and there is no chance for the District Secretariat or the politicians living within the proposed district to grab any 
land beyond the limits of the district boundary. Matters pertaining to land settlement and distribution are carried out by the respective authorities of the central line ministries, with the District Secretariats merely facilitating these functions, unless the central authorities and bureaucrats at District Secretariats made decisions favoring any particular ethnic group, as had happened in the Amparai district earlier.

Therefore, it is found that the criticisms posed by the Sinhalese public and nationalistic forces are hardly judgmental and are mainly expressed in order to oppose any initiative for decentralization and power-sharing with the ethnic minorities. The history of opposition politics reveals that the Sinhalese failed to identify the rationale behind the minorities' demands for power-sharing and decentralization, including the Kalmunai district demand. However, a small group of people, mostly academics and leftists, support the new district demand to a certain extent, viewing it to be in line with public service delivery, regional development, good governance, and the accommodation of minority rights. However, given that hegemonic ethno-nationalism has re-emerged and dominated the whole sphere of public life in Sri Lanka, the rationalist views and expressions have always been undermined.

\subsubsection{Opposition and Criticisms from the Tamils}

The demand for Kalmunai administrative district has also received strong criticisms from the Tamil community, hence undermining it further. Initially, both the Muslims and the Tamils of the region had jointly advocated the proposed administrative district as it would help to resolve linguistic and other issues faced by both ethnic groups. The cohesive politics of both ethnic groups had strengthened the advocacy of the demand to a certain extent. Many Muslim politicians in this region succeeded in their political career through coalition with the major Tamil political party, the Federal Party (FP). Initially, not only the Tamil public but the Tamil politicians too supported the Kalmunai administrative district demand as it would benefit the two communities. However, in time, especially after the intense and violent ethnic conflict and civil war, the ethnic relations between the Muslims and the Tamils in the north-eastern provinces deteriorated and both ethnic groups became politically separated. The Tamils' nationalist struggle showed its interest in the Tamils only, and even targeted the innocent Muslims in the north-eastern region, forgetting the fact that they share with the Muslims the Tamil language as a feature of their ethnicity. The Muslims were also ethnically mobilized through a distinct Muslim political party which advocated the rights and interests of the Muslim community, especially those living in the northeastern region. Thereafter, the divisions and conflicts between the Tamils and the Muslims increased in the north-eastern region, including in the Amparai district.

The establishment of a Muslim political party, the Sri Lanka Muslim Congress (SLMC), under the leadership of MHM.Ashraff intensified the advocacy of the Kalmunai administrative district together with the demand for a Muslimmajority political autonomous unit for the sake of the Muslim community living in the north-eastern region. This Muslims' autonomy claim was viewed by the Tamils as opposed to their ethnic politics and their advocacy for a separate state in the north-eastern region. Therefore, they opposed both the Muslims' demand for Kalmunai administrative district and the Muslim-majority politically autonomous unit. When the SLMC leaders seriously advocated the Kalmunai administrative district demand in 2000, the Tamils in the Amparai district protested and appealed to the government authorities and President to stop the initiative. It was noticed from the field survey that a number of the Tamil public and local politicians expressed their resistance on the matter, although a few were able to appreciate the rationale for the establishment of the proposed administrative district.

This study has identified a number of factors which have induced the oppositions by the Tamils towards the Kalmunai administrative district demand. Many local Tamils feel that since SLMC has been advocating the proposed district as a Muslim-majority district, this would only benefit the Muslim community and lead to the Tamils being marginalized under administration of the new district. To a certain extent, this argument or feeling is understandable, as many SLMC leaders had made mistakes in this regard. As pointed out by many Tamils and other critics of the demand, up till now, the SLMC leaders have not sought to engage in any discussion or negotiation with the Tamil politicians and the civil forces regarding the importance of establishing the proposed district and the benefits which it will bring to both communities. Yet, they are appealing for support from the Tamil political parties and the public. Notwithstanding, the Tamils' argument that the establishment of the proposed district would benefit only the Muslims and lead to the marginalization of the Tamils cannot be easily justifiable. It is obvious that the Muslims would form the majority in the proposed Kalmunai district's population as presently the Sinhalese live in 17 districts, the Tamils in 6 districts and the Muslims in 2 districts. But, as Noorul Haqu (Personal communication, 3 August, 2014) argued, there is no historical record showing that the Muslims have dominated the administration of any district in Sri Lanka, even though they form a majority of the population in two districts, namely in Amparai and Trincomalee. Further, according to Noorul Haqu (Ibid), 
the Muslims will not try to dominate the administration of the proposed district because doing so would impact the Muslims living as minority communities in other districts. Therefore, if the organization of the proposed district's administration is clearly designed, taking into considering ethnic sensitivities in sharing power, positions, and resources, the possibility of ethnic domination by the Muslims would be minimal.

Regardless, the Tamils must accept the fact that the establishment of the proposed district would definitely resolve the linguistic issues facing by members of both ethnic groups, namely the Tamils and the Muslims. It was observed through the field survey that many Tamils agree that the proposed district would allow them to fulfill their needs in their own native language. It was noted that many Tamils also acknowledged that under the present district administration-at the District Secretariat-they also face difficulties due to the domination by the Sinhalese and the Sinhala language. Therefore, the Tamils' opposition to the proposed district is not entirely reasonable.

Another factor that motivated the Tamils to oppose the proposed Kalmunai district is the lack of political support rendered by the Muslim public and politicians towards the Tamils' political struggles and initiatives and their demands to fight for the rights and interests of the Tamils as well as to resolve the administrative issues facing by them. An example of this would be the demands calling for the establishment of a full-fledged Divisional Secretariat (DS) in Kalmunai (Tamil division) and Grama Niladari (GN) divisions in many Muslim-majority areas on the coastal belt of Amparai and other districts (IN.10-12, Personal communications, 13 September, 2014). Some aspects of the above argument are true to a certain extent. It is obvious that the Muslim leaders, especially the SLMC leaders, have not openly supported or publicly advocated the upgrading of the Kalmunai Tamil DS division into a full-fledged one, despite this being a long-term demand posed by the Tamils in the Kalmunai area. On the other hand, the Tamils cannot fully deny the support extended by the Muslims for their nationalist movement and struggles. From the beginning of the Tamils' political struggle for rights and recognition, the Muslims have allied with them as fellow Tamil-speaking people. The famous Muslim leaders, including the founder of the SLMC, the first successful distinct Muslim political party in Sri Lanka, have also accepted the concept of self-determination of the Tamils and their struggle for a separate state. (See: Sarjoon 2001 \& Yusoff et al., 2014). Unfortunately, when the Tamils turned their political struggle into a violent one, they targeted the Muslims, failing to consider them as fellow Tamil-speakers and disregarding their contribution to the Tamils' nationalist struggles.

The Muslims in the north-eastern region were compelled to mobilize politically and to form a political party based on their own ethnic line. They separately advocated their own rights and interests as a reaction to ethnic and political marginalization by the Tamils (and the Sinhalese). When Tamil militant groups began to violently target the lives and livelihood of innocent Muslims in the districts of the north-east, the Muslims' political mobilization and their advocacy for Muslim-oriented demands were also strengthened. However, it is worth highlighting that in the process of political mobilization, the Muslims never attempted to undermine the Tamils' struggles and their nationalist movement. The Muslim leaders chose non-violent means to voice out their rights and to save their community through political and administrative institutional arrangements. Hence, the demands for a Muslim-majority autonomous unit and a Muslimmajority administrative district emerged. It is ironic that the Tamils have also been experiencing administrative grievances at district and divisional levels in the Amparai district. It is obvious that Muslim politicians have not extended their support to resolve Tamils' grievances, including the upgrading of the Kalmunai Tamil DS division into a full-fledged DS division. However, being opposed to the establishment of the proposed Kalmunai district would not resolve these problems. Leaders of both ethnic groups must unite and co-operate in this regard; cohesive politics would strengthen the ethnic and socio-economic relationships of both ethnic groups living in this region as well as empower their political advocacy, for the sake of their community rights and interests.

\subsection{The Criticisms and Opposition Expressed by the Major Political Parties towards the Kalmunai Administrative District Demand}

This study has found that the communalized criticisms and oppositions expressed by major political parties within and outside parliament has caused difficulties in the achievement of the Kalmunai administrative district demand to a certain extent. Political parties are the gatekeepers who turn public issues into "demands" and push them forward as "input" to the political system. Therefore, it is the responsibility of the political parties functioning on principles of democracy to consider the impact of such issues in society and bring them into the political system in order to find solutions. As a political party representing the Muslim community in particular, the Sri Lanka Muslim Congress (SLMC) has been calling for the establishment of the proposed Kalmunai administrative district within and the outside parliament for the last 30 years. But, as is usual in Sri Lankan political culture, no party has shown its strong support for the demand both within and outside the parliament. Whenever, the Kalmunai district demand was put forward in parliament and emphasized at 
societal level, the demand was met with immediate criticisms and oppositions from major political parties representing both Sinhalese and Tamils. In contrast, whenever the SLMC's support was crucial for those parties to sustain their political power, they would always be silent. Even though the fulfillment of the demand, i.e., the establishment of the proposed district, would be beneficial for the Tamils living in the proposed district, no Tamil party has expressed its strong support for the demand either within or outside parliament. In the post-war context, the demand received strong criticisms and oppositions from almost all major political parties in Sri Lanka. The following sub-sections review the trend, nature, and extent of the censures and oppositions expressed by the major political parties throughout history with regards to the Kalmunai administrative district demand.

\subsubsection{The Stance of the United National Party (UNP)}

The UNP is one of the two major national level political parties which has ruled the country for nearly half of the postindependence era. Since its establishment, it has been following the path of liberal democracy, and a majority of Sri Lankan Muslims have also been supporting it. When the Muslim organizations and parties initially put forward the Kalmunai administrative district demand in the beginning of 1980s, there was no consensus among the UNP leaders to accept and fulfill the demand even though the UNP was in power, with three Muslim parliamentarians representing the party from the coastal area of Amparai district. At the time, the UNP-led government had shown its interest to explore the demand, but this was opposed by some Sinhalese parliamentarians from the UNP, especially those representing the Amparai district. Therefore, the initiative was abandoned by the government (IN.02, Ibid \& Noorul Haqu, 2002:19). At the time, the UNP government had secured five-sixth majority in parliament and had made a number of constitutional amendments, including one which established the Kilinochchi administrative district in 1984 even though this was not strongly demanded or advocated by the people of northern Tamils as compared with the Muslims' demand in the coastal belt of Amparai. In the later part of 1980s and the beginning of 1990s, the UNP government under President Premadasa intended to fulfill the demand, but due to high pressure and opposition from the Sinhalese and Muslim parliamentarians representing the Amparai district, the government abandoned such initiatives (IN.02, Ibid \& IN.13, Personal communication, 9 August, 2014). On the other hand, since the beginning of the 1990s, the successive governments formed by the UNP or SLFP focused on the military defeat of minorities' demands and claims for power-sharing and autonomy, therefore there was no room for Muslims to convince the leaders to establish the proposed Kalmunai district.

A slight change was seen in UNP's stance towards the demands of minorities from the beginning of 2000 . When the UNP formed the government with the support of the SLMC after the December 2001 general elections, the UNP leaders were compelled to consider the SLMC'S demands for the establishment of the Kalmunai administrative district. The UNP-led government made initiatives to establish the proposed Kalmunai administrative district. Unfortunately, due to lack of unity and consensus among the Muslim leaders, i.e., between the SLMC leaders and the leaders of the National Congress, a party emerged from the split within SLMC on the matter of naming the proposed district and placing its secretariat, the government had easily abandoned those initiatives (Skynetbit.com, 2005). Additionally, the UNP had accepted the Kalmunai district demand as part of its 2005 Presidential election manifesto, to be fulfilled if its candidate was elected to the Presidency. This was unsuccessful since the UNP candidate lost the election. However, as Hasan Ali (Personal communication, 8 August, 2014) revealed, there was a mutual understanding between the SLMC and the UNP on the matter of Kalmunai administrative district which led to the electoral coalition between the SLMC and the UNP in the eastern provincial council election and the general election held in 2008 and 2010 respectively.

When the SLMC leaders once again came to insist on the establishment of the Kalmunai administrative district in the later part of 2014, some UNP MPs resisted and seriously criticized this on communal lines at parliament, which was not opposed by the first level leaders of the party. In responding to the SLMC's demand, the UNP MP, Vijadasa Rajapacksha commented that "it is a silly argument to say that they need to carve out a separate administration district claiming that the administration is done in Sinhala" (Indrajith, 2014). He further associated the Kalmunai administrative district demand to be equal to the LTTE demand for a separate state (See: Parliament Secretariat, 2014). His criticisms received much support from other parties and also induced them to further communalize the demand. However, the UNP national leader and other leaders did not oppose or comment on Vijedasa's speech and criticisms in this regard.

It is worth noting that the UNP, the first party introduced the decentralization initiatives at district level in Sri Lanka to reconcile ethnic grievances and boost economic and regional development, has continuously failed to positively consider the Kalmunai district demand. As many advocates of the demand reveal, the fulfillment of the demand would resolve the linguistic issues facing by the Tamil-speakers and support the regional development to a certain extent. 


\subsubsection{The Stance taken by the Sri Lanka Freedom Party (SLFP) and the United People Freedom Alliance (UPFA)}

Aside from the UNP, the Sri Lanka Freedom Party (SLFP) is the other party which has nation-wide reputation, political support, and representation in Sri Lanka. Similar to the UNP, the SLFP has also ruled the country for half of the postindependent era. As a socialist party, it received support from the lower and middle segment of society and worked for the empowerment of the rural public. However, the Muslims' support for the SLFP was minimal until the SLMC formed a coalition with the SLFP-led People's Alliance (PA) government in August 1994 (Aliff and Sarjoon, 2010 \& Imtiyas, 2012). The SLMC leader, Ashraff, as a king-maker in the PA government, was very much influential within the cabinet and was able to put forward the party's long-term demand for a Muslim-majority autonomous unit in the merged north-eastern province. He was able to convince the coalition parties to incorporate this demand in the negotiation settlement process. However, there were strong criticisms for the SLMC's demand within the government. At the last stage of the PA government, the SLMC leader urged the government to establish the proposed Kalmunai district as the first step towards resolving the administrative issues facing by the Tamil-speaking people in that area. However, the government delayed this process and this ultimately led the SLMC to break up its relations with the SLFP-led coalition government just few days before the October 2000 general election.

During the 2000 general election, the SLMC requested a mandate from the people of Amparai coastal area to push the new government to establish the proposed Kalmunai district. However, the general election once again produced a hang-parliament with no major party receiving a majority to form a government. The election once again produced government-making power to the SLMC. Since the SLMC won 4 seats in the Amparai district with overwhelming support from the Muslims in the coastal belt, it bargained for the formation of the Kalmunai district matter with the PA in order to form the coalition government. At last, SLMC formed an alliance with the SLFP-led PA, while agreeing on a number of important demands, including that for the establishment of the proposed Kalmunai district within 100 days. In the beginning, the SLFP-led government had tentatively agreed to the establishment of the proposed district and had made some arrangements towards this, including the preparation of the necessary papers for a one-man commission to look into the matter and report to the minister in charged (Sathyapalan, 2001). However, the stiff resistance which existed within the SLFP and coalition parties in the cabinet eventually led to the rupture of the SLFPSLMC coalition and compelled the SLMC to withdraw its support for the government within one year. This later caused the SLFP-led PA to lose its ruling power.

The SLFP came into power again in 2004 when it won the general election under the United People Freedom Alliance (UPFA), a formation of alliance with many leftist parties. Later, many Sinhalese nationalist parties also supported the government. Since more fragmentation occurred within the SLMC, with more nationalist and anti-Muslim forces gathering within the SLFP-led government, SLFP leaders easily neglected the SLMC's demand for Kalmunai administrative district despite the SLMC representatives extended their support for the UPFA government. Later, from 2010 onwards, SLFP leaders further gave promises and made agreements with the SLMC while adopting the Eighteenth Amendment to the constitution (adopted in September 2010) and forming the eastern provincial council in September 2012 (Hasan Ali, Ibid \& Parliament Secretariat, 2014). However, until SLFP was in power (up to January 2015 presidential election), the SLFP or SLFP-led UPFA leaders failed to honor the agreements reached with the SLMC regarding the Kalmunai administrative district matter, and they failed to form the proposed district.

It is worth noting that whenever the SLMC supported important policy decisions and acts, including the constitutional amendment favoring the SLFP-led UPFA government and its leaders, there were no criticisms towards the SLMC's demand for the Kalmunai administrative district. On many occasions when the both SLMC and SLFP leaders agreed to consider and establish the proposed district, none of the coalition partners or the leaders of the SLFP or SLFPled UPFA opposed or voiced out against the demand. Yet, when the SLMC repeated its demand just before it decided to leave the UPFA government in December 2014, many SLFP leaders and leaders of the coalition parties harshly criticized and expressed their oppositions towards the demand on negative communal lines. The SLFP's senior member and the Prime Minister of the SLFP-led UPFA government, DM.Jeyarathe, strongly supported the argument made by the UNP MP, Wijedasa Rajapcksa, in opposing the SLMC's demand for Kalmunai administrative district in parliament (See: Parliament Secretariat, 2014 \& Tamil Guardian, 2014). When the SLMC left the SLFP-led UPFA coalition government and extended its support to the opposition Presidential candidate, the SLFP secretary general, Anura Priyadarshana Yapa reported that "the SLMC attempts to realize one more goal in the international conspiracy to make Sri Lanka an unstable country. Establishing a separate administrative district for Muslims can cause damage to peace and unity in the motherland. The SLMC's demand is extremely similar to the LTTE demand for Eelam. SLMCers are trying to push separatism in Sri Lanka and create an unstable situation that would harm peace, harmony, reconciliation, social and 
economic development" (Dissanayake, 2014).

In fact, the Muslim community strongly opposed the support extended by the SLMC representatives to the SLFPled UPFA government on many important and controversial policy decisions taken both during and after the civil war. The Muslim community in general and the north-eastern Muslims in particular bore a number of grievances regarding having their ethnicity recognized and practicing their religion. Their physical entities also became the target of severe violence in many parts of the country (See: Farook, 2014; Senaratne, 2014 \& Yusoff and Sarjoon, 2016). All these incidents significantly pressured SLMC leaders to withdraw their support for the SLFP-led government. However, the SLMC leaders continued to stay with the government, expecting their demands, including their demand for the Kalmunai administrative district, to be fulfilled. In the end, the SLFP not only broke the promises they made to the SLMC on the Kalmunai administrative district demand, but also opposed and criticized it with brutal and harsh words.

Apart from the above two major political parties, a number of other parties representing the Sinhalese and other nationalist forces have also criticized and expressed their resistance towards the Kalmunai administrative district demand on many occasions. Most of them shared the same opinion regarding this demand whenever they aligned with the two major political parties. It is interesting to note that whenever the major parties accepted the demand, most of the coalition parties fell silent and whenever the major parties opposed it, these coalition parties echoed their opposition and criticisms. There was no firm stance on this Kalmunai administrative district matter among any political party in general.

\subsubsection{The Stance taken by Major Tamil Political Parties}

Although the Tamils and the Muslims living in the north-eastern region have been proudly stating that they have a long history of mutual understanding and co-operation in all aspects of life including in politics, in reality many differences emerged between the two groups following the intensity of the ethnic conflict. It is true that both ethnic groups enjoyed a cohesive politics and mutually advocated for the rights (including the rights of self-determination and self-rule) of both groups under the slogan of "Tamil-speakers." When the Muslims supported the major Tamil political party, the Federal Party (FP-later Tamils United Liberation Front-TULF) in the 1950s and 1960s, leaders of the FP, as a policy, accepted the necessity of establishing a Muslim-majority federal unit in the eastern province in order to accommodate the Muslims' rights and interests for political autonomy within the federal form of government. When Celvanayagam, the leader of the FP, made an agreement with SWRD Bandaranayake, the then Prime Minister of Sri Lanka in 1957, he incorporated a provision to form more federal units in the eastern province to accommodate other ethnic groups aside from the Tamils, and especially to respect the self-rule of Muslims (See: Ghose, 2003; Sarjoon, 2011 \& Yusoff et al., 2014). Similarly, the Muslim leaders had also accepted the resolution passed by the TULF leaders for the establishment of a separate state for the Tamils in the north-eastern region in 1976. During the 1977 general election, many Muslim leaders, including MHM.Ashraff, advocated the concept of a separate state for the Tamils and worked towards achieving it. However, when the Tamils' non-violent political advocacy failed, it transformed into a violent movement controlled by the Tamil militant groups after the 1977 general election, which only advocated the rights and interests of the Tamils alone. This in turn prompted the Muslims to search for their own political institution in order to safeguard their existence, identity, and rights within the region. With the emergence of a separate Muslim political party, the SLMC, in the mid-1980s, ethnic relations between the two groups further deteriorated and the two groups became political opponents. All Tamil rebel groups opposed and undermined the establishment of a Muslim political party and its political demands including the demand for autonomy and decentralized powers for Muslims. Since all major Tamil parties were under the control of the militant groups who resorted to violent means to achieve their aims, no political party or forces representing Tamils had openly expressed their support for the causes and the demands of the Muslims, including the proposed Kalmunai administrative district demand.

As stated earlier, the demand for the establishment of the Kalmunai administrative district was initially conceptualized and advocated by both Tamil and Muslim political leaders who worked together with mutual trust. However, the civil war led to the break-up of ethnic relations between the Tamils and the Muslims. Tamil politicians continued to oppose many of the Muslim demands, including the demand for the proposed Kalmunai administrative district. Despite this, the SLMC's founder leader, MHM.Ashrff, maintained cordial relations with the major political leaders of the Tamil community, especially with the leaders of the TULF. On the other hand, no record is available evidencing support from any Tamil political party or leader for the SLMC's demand for the proposed administrative district. To date, no political party has openly expressed its strong opposition towards the proposed district either. However, in the recent past, whenever the Sinhalese politicians and nationalist forces criticized and openly opposed the demand, some Tamil politicians and political forces at local level had also expressed their negative viewpoints on the same. Further, they 
questioned the sincerity of the Muslim political parties in supporting the advocacy of the rights of the Tamils.

During the field survey for this study, the criticisms and opposition expressed by some local level political leaders and representatives of Tamil parties concerning the subjects of the Kalmunai administrative district demand were noted. Though a majority of them accepted that the establishment of the proposed district would facilitate them in fulfilling their administrative tasks in their own language and would support the development of their socio-economic conditions, their main concern was that the Tamils would be marginalized and their interests would be neglected under the administration of the proposed district dominated by the Muslims (IN.11 \& IN.12, Ibid). A majority of the interviewees who participated in the field survey also acknowledged the lack of political understanding between the Tamil-Muslim political parties and leaders as being one of the major factors challenging the feasibility of the fulfillment of the Kalmunai administrative district demand. Even though the TNA and the SLMC and their leaders have been publicizing the fact that both ethnic groups and their political parties must unite and work together for their mutual betterment, to date no meaningful initiative has been taken towards this, including towards the establishment of the proposed district. Since both ethnic groups have been facing similar issues in terms of district administration in Amparai, the collaborative efforts by political parties and leaders of both ethnic groups would strengthen the advocacy of the demand and influence the policy-makers and political authorities to consider the demand positively.

\section{Concluding Remarks}

In the aftermath of civil war, Sri Lanka's politics became highly communalized. Many minority demands, despite being based on rational grounds, were viewed through ethnic lenses and were thus strongly criticized and opposed by ethnic majorities and the political parties representing them. The Kalmunai administrative district demand, which was once popularly advocated by the Tamil-speaking Muslims and Tamils living in the coastal belt of the present Amparai district in 1960s, suffered the same fate. Both ethnic groups faced similar administrative problems such as violation of their right to access public services in their own language (in Tamil), the domination of Sinhala language in district administration, the location of the District Secretariat, ethnic marginalization and the domination of the Sinhalese in district administration and resource utilization. Due to this, both ethnic groups and their leaders collectively voiced out these administrative grievances and advocated the demand calling for the establishment of a separate administrative district (Kalmunai) for their predominant area. However, following the intense civil war, this administrative district demand became mostly favored by the Muslims alone, who form majority in the proposed district, and came to be opposed by the other ethnic groups and their leaders.

As set out in this paper, there are rationales behind the Kalmunai administrative district demand. To a certain extent, the establishment of the proposed district would help to resolve the administrative grievances of those living within the proposed district and would potentially bring other positive effects such as the improvement of public service delivery, enhancement of socio-economic conditions and regional development, and strengthening of ethnic cohesion in the region. However, both the Sinhalese and the Tamils (and their political parties) continued to view the demand on ethnic lines and failed to acknowledge the grievances that the Muslims face in terms of district administration. The arguments expressed by the opponents to the Kalmunai district demand are somehow ethnic-oriented and cannot be easily justifiable. Despite criticisms by the Tamil leaders and public, it was obvious that the establishment of the proposed Kalmunai district will not empower the Muslims alone, but also the Tamils.

It is worth pointing out that major political parties have chosen to communalize the Kalmunai administrative district demand differently in different contexts. Almost all major political parties, in different political and electoral contexts, have at one time or another accepted the Kalmunai district demand and agreed or promised to form the proposed district. Yet, contrary to these promises, they later criticized and opposed the demand on communal lines. In Sri Lankan context, an administrative district functions as an intermediate institution facilitating the delivery of a number of public services offered by the central ministries and departments at local level. Therefore, it is obvious that the District Secretariats merely exercise a form of decentralized power-known as de-concentration. Yet, the Kalmunai district demand was still strongly resisted by the ethnic majorities-the Tamils and the Sinhalese-and by the major political parties, where they viewed the demand as calling for more political autonomy and a separate state for Muslims in the region. This clearly indicates that the criticisms and oppositions expressed towards the Kalmunai administrative districts demand are largely irrational and adopted on communal basis. This study also found that the major political party advocating the Kalmunai administrative district demand - the SLMC —-has also highly ethicized the demand and sought to justify it on the basis of ethnicity. Finally, this study suggests that conceptualizing and advocating the proposed administrative district on rationale grounds would potentially make the demand successful. 


\section{Reference}

Aliff, S.M \& Sarjoon, A. (2010). The break-up of Sri Lanka Muslim Congress: A critical analysis of the causes and the impacts in the Muslim politics of Sri Lanka. In D.Devanathan, C.Subramanian \& D.Sivakumar (eds). Globalization: Problems and prospectsVol.ii (pp.12-24). Chennai: SCITECH Publications (India) Pvt Ltd.

Department of Census and Statistics. (2014). Census of population and housing-2012 (New) - Final report. Colombo: Department of Census and Statistics [online] Available: http://www.statistics.gov.Ik/PopHouSat/CPH2012Visualization/htdocs/index.php ?usecase=indicator\&action=Map\&indld=10 (December 20, 2014).

Dissanayake, R. (2014). SLMC is now a LTTE: Hakeem left as govt. did not agreed to establish separate administrative district for Muslims. Daily News, 30 December [Online] Available: http://www.dailynews.lk/?q=local/slmc-now-Itte\#sthash.Trbdv7oA.dpuf (January 20, 2015).

Farook, L. (2014). Sri Lankan Muslims: meticulously planned and executed to military precision. [Online] Available: http://www.latheeffarook.com/index.php/srilanka-muslims/1152-killing-of-muslims-in-sri-lanka. (January 4, 2015).

Ghosh, P.S. (2003). Ethnicity versus nationalism. Colombo: Vijitha Publications.

Hasbullah, S.H., Balasundarampillai, P \& Tudor Silva, K. (2005). Addressing root causes of the conflict: Land problems in the north-east Sri Lanka. Colombo: Foundation for Co-Existence.

Ibrahim, I.L.M. (2002). Kalmunai coastal district. Sammanthurai: Author's Publication.

Imtiyas, A.R.M. (2012). Identity, choice and crisis: A study of Muslim political leadership in Sri Lanka. Journal of Asian and African Studies, 48(1), 47-63.

Indrajith, S. (2014). Wijeyadasa tears into SLMC demand for separate unit for eastern Muslims: PM endorses UNPer's view. The Island. 4 November [Online] Available: http://www.island.Ik/index.php?page_cat=article-details\&page =article -etails\&code_title=113515 (November 15, 2014).

Iniyavan. (2014). The fundamental issues of the Tamils in Amparai district need to be resolve prior to the formation of coastal district. Tamil Diplomat, 31, December [Online] Available: http://tamildiplomat.com/the-fundamental-issues-of-the-tamils-in-amparadistrict-need-to-be-resolved-prior-to-the-formation-of-coastal-district/ (April 4, 2015.)

Jabbar, M.A. (2013). Creation of new administrative district for Tamil-speaking people in Amparai: a critical analysis. Kalam: research journal of faculty of arts and culture, 7, 80-92.

Leitan, G.R.T. (1979). Local government and decentralized administration in Sri Lanka. Colombo: Lake House Investments Ltd.

Mohideen, M.I.M. (2008). Sinhalisation of east: a reply to minister Champika Ranawaka [online] Available: http://www.island.Ik/2007/12/27/features5.html (December 12, 2014).

Mohideen, M.I.M. (2013). Eastern Muslims must unite politically. Colombo: Al-Ceylan Muslim Documentation Center.

Noorul Hagu, M.M.M. (2002). Minorities: some observations. Sainthamaruthu: Marutham Kalai llakkiya Vattam.

Parliament Secretariat. (2014). Parliamentary debates (Hansard) official report. 231(16), 3041-3046.

Pradeep, A. (2008). Sinhalization of the east: myths and realities the Sinhalese have always been generous and kind to the Muslims: a reply to M.I.M.Mohideen. The Island, 25 January [Online] Available: http://www.island.Ik/2008/01/25/features2.html (April 23, 2015).

Rameez Abdullah, M.A. (2005). Ethnic harmony in eastern Sri Lanka. In G. Frerks \& B. Klem (eds.). Dealing with diversity: Sri Lankan discourses on peace and conflict (pp.183-190). The Hague: The Netherlands Institute of International Relations.

Sarjoon, A. (2001). The leadership of M.H.M.Ashraff in Muslim politics of Sri Lanka: a critical analysis. Undergraduate Dissertation. Oluvil: South Eastern University of Sri Lanka.

Sarjoon, A. (2011). Changing dynamics of minority rights discourse in Sri Lanka's eastern province: A study of the Muslim demand for autonomy. M.Phil Thesis. Colombo: University of Colombo.

Sarjoon, A. Yusoff, M.A, Hussin, N \& Awang, A. (2015). The demand for an administrative district for the costal belt of Amparai district in Sri Lanka: an assessment of its root causes. Mediterranean Journal of Social Sciences, 6(4S3), 434-443.

Satyapalan, F.R. (2001). Hakeem group to withdraw support to PA? The Island. [Online] Available: http://www.island.Ik/2001/06/13/news18.html (April 30, 2015).

Senaratne, K. (2014). Politics of Alutgama. Colombo: Ground View. [Online] Available: http://groundviews.org/2014/06/22/the-politicsof-aluthgama/ (January 4, 2015).

Skynetbit.com. (2005). Mahanida had no plans for Kalmuani coastal district-Hakeem. [Online] Available: http://skynetbit.blogspot.com/2005/10/mhanida-had-no-plans-for-kalmuani.html (July 10, 2014).

Tamil Guardian. (2014). Government rejects SLMC demand for spate administrative district for Muslims. Tamil Guardian, 4 November [Online] Available: http://www.tamilguardian.com/article.asp?articleid=12774 (April 24, 2015).

Thinakkural. (2001). 26 May.

Veerakesari. (2001). 28 May.

Yusoff, M.A \& Sarjoon, A. (2016). On the margin: a critical assessment of Muslims' concerns in the post-war development and settlement process in Sri Lanka. Conference Paper. $8^{\text {th }}$ International Conference on Innovation in Humanities and Social Sciences. National Defense University of Malaysia. Kuala Lumpur. 27-28, May.

Yusoff, M.A., Sarjoon, A., Hussin, N \& Awang, A. (2015a). Public administration and minority language: The case of district administration in Amparai, Sri Lanka. Public Administration Research, 4(2), 31-44.

Yusoff, M. A., Sarjoon, A., Asrinaldi \& Mohd Zain, Z. (2015b). Decentralized administration and minority accommodation in Sri Lanka: 
analyzing status, issues, challenges and prospects. Mediterranean Journal of Social Sciences, 6(4S1), 533-542.

Yusoff, M.A., Hussin, N. \& Sarjoon, A. (2014). Muslim demand for territorial autonomy in the Eastern Sri Lanka: an analysis of its origin, accommodation and the present stance. Asian Social Science, 10(15), 76-88. 
